آناليز حساسيت يارامترهاى هيدروليكى محيط متخلخل در حل معكوس انتقال بروميد فريده انصارى'، سيدحسن طباطبائى '، فريبرز عباسى و ابراهيم علايى (تاريخ دريافت: \& |

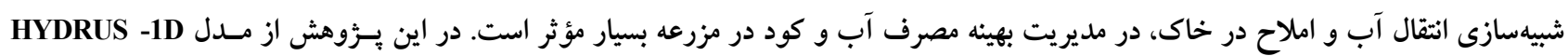

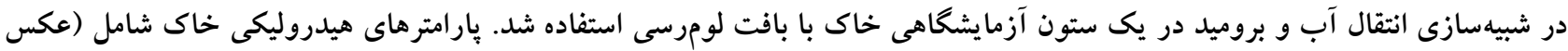

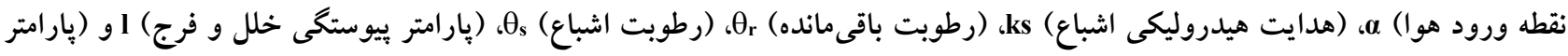

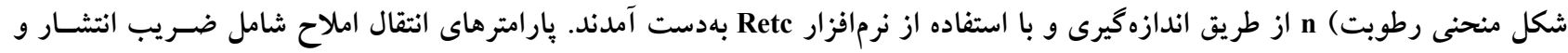

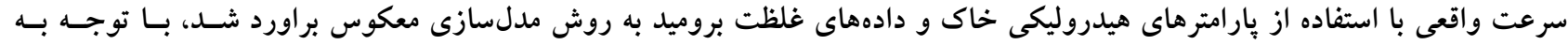

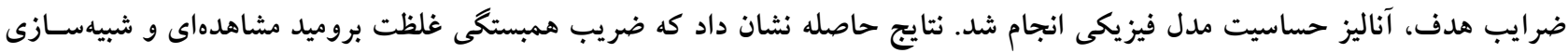

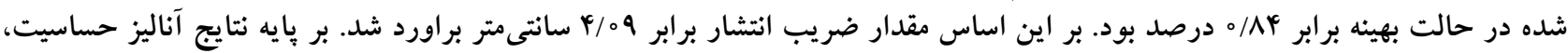

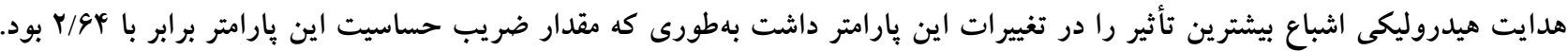

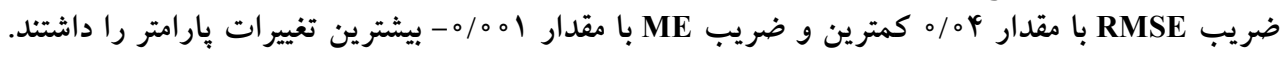

وازمهاى كليدى: بخشيدگى، شبيهسازى، برومايد، HYDRUS

ا. كروه مهندسى آب، دانشكده كشاورزى، دانشگاه شهركرد ז. مؤسسه تحقيقات فنى و مهندسى كشاورزى، سازمان تحقيقات، آموزش و ترويج كشاورزى، كرج

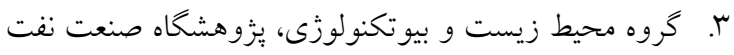
*: مسئول مكاتبات: بـست الكترونيكى: Tabatabaei@agr.sku.ac.ir 
كه در آن D: ضريب انتشار (M (M L

مورد نظر (ML و 1 و : زمان(T)

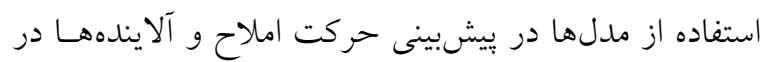

خاك، مىتواند موجب صرفهجويى زيـاد در وقـت و هزينـهــا

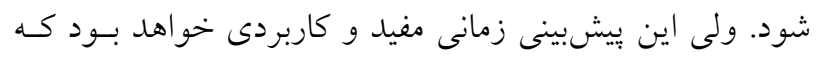

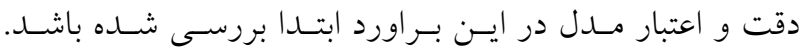

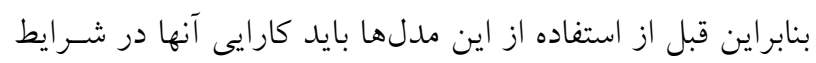

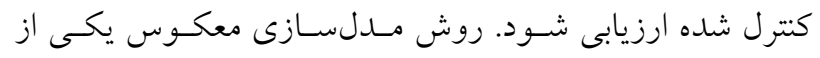
روشهاى غيرمستقيم براى تخمين ويزگى هاى خاك اسـت كـه

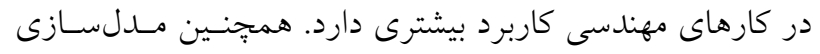
معكوس توانايى براورد همزمان ويزگگ هاى هيدروليكى و انتقال

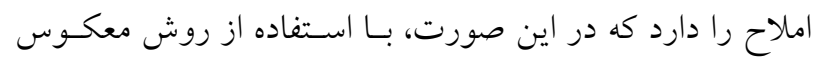

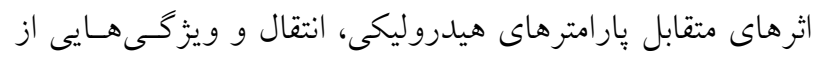

خاك درنظر كرفته مىشود (1). مدل HYDRUS يكى از مدلهاى بيشرفته با قابليت شبيهسازى

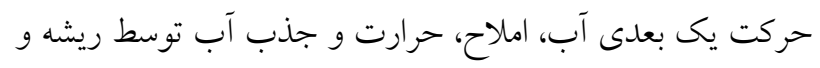

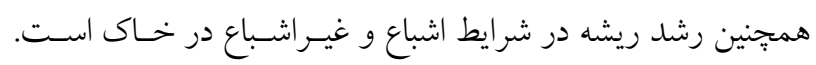

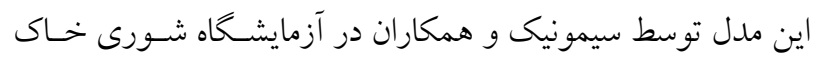

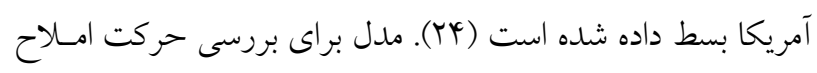

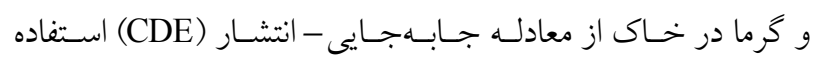

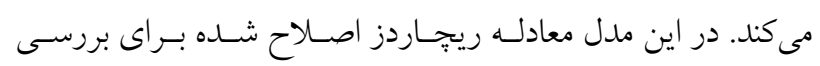

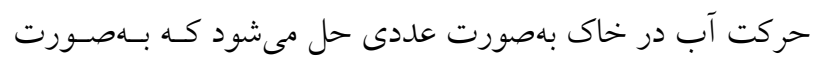
معادله (Y) بيان مىشود (TQ).

$\frac{\partial \theta}{\partial \mathrm{t}}=\frac{\partial}{\partial \mathrm{t}}\left[\mathrm{K}(\theta)\left(\frac{\partial \mathrm{h}}{\partial \mathrm{x}}+\cos \beta\right)\right]-\mathrm{s}$

در معادله ريجاردز براى توصيف مشخصـات هيـدروليكى خـاك

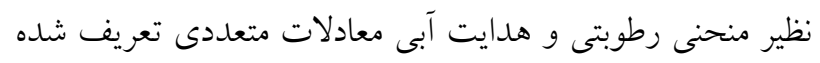

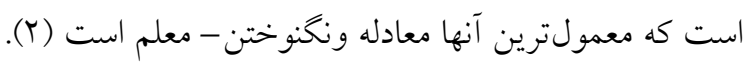

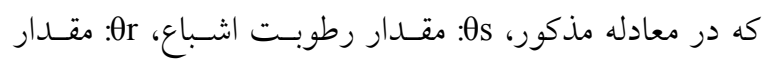

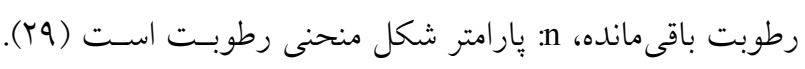

منابع محدود آب در صورتى قابل استفاده خواهد بود كه كيفيت

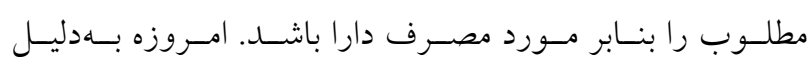

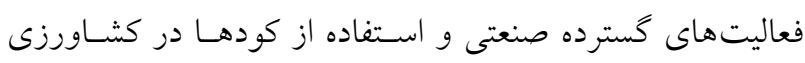

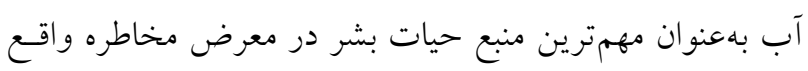

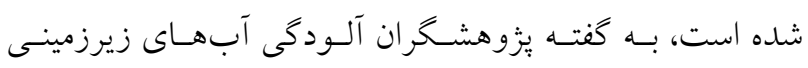

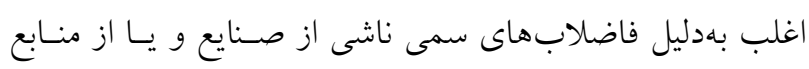

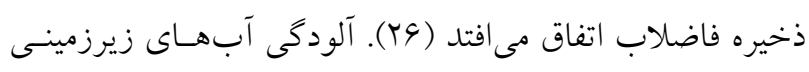

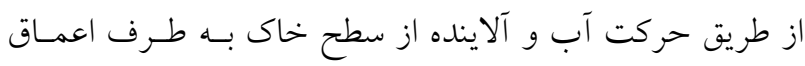

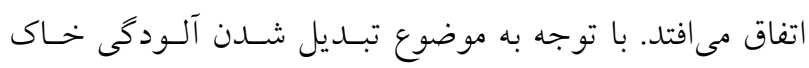

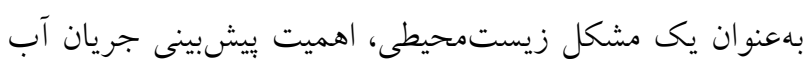

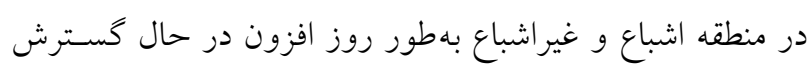

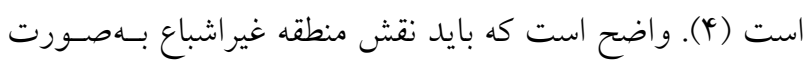

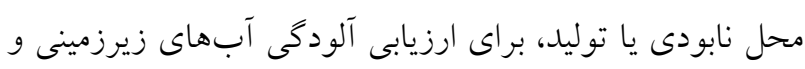

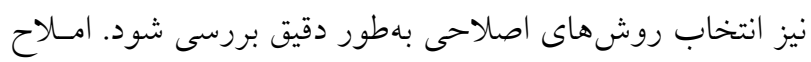

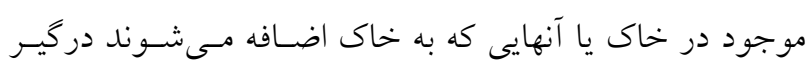

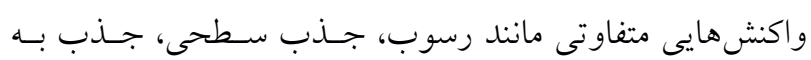

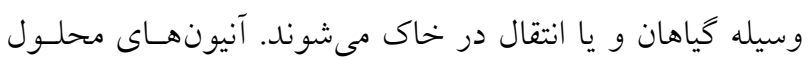

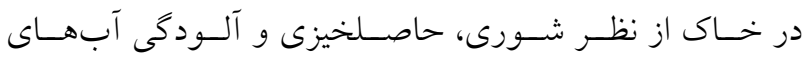

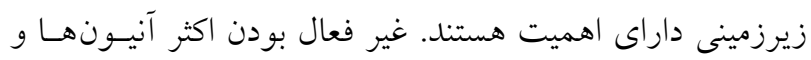

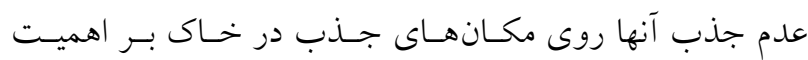

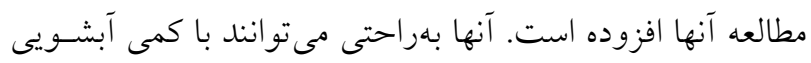

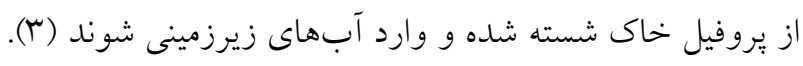

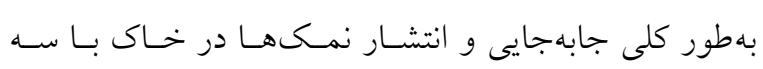

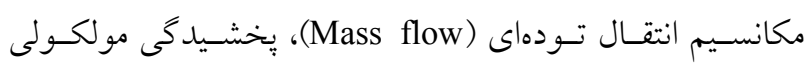
(Diffusion) مىشود. با در نظر كرفتن تأثير همزمان اين سه فرايند بر حركت

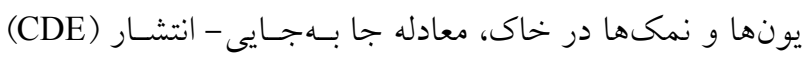

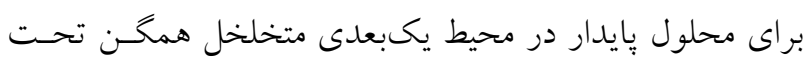
شرايط جريان دائمى بلصورت زير است (19). $\frac{\partial \mathrm{C}}{\partial \mathrm{t}}=-v \frac{\partial \mathrm{C}}{\partial \mathrm{C}}+\mathrm{D} \frac{\partial^{r} \mathrm{C}}{\partial \mathrm{z}^{r}}$ 
دارد. دامنه ضريب همبستخى بـين مقـادير شـبيهسـازى شــه و

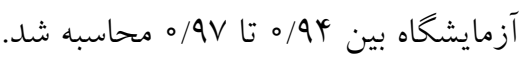

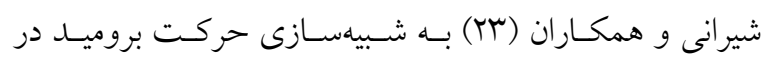

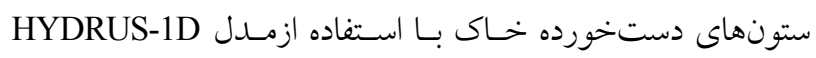
يرداختند. نتايج نشان داد كه مدل بيشترين حساسيت را به تغييـرات

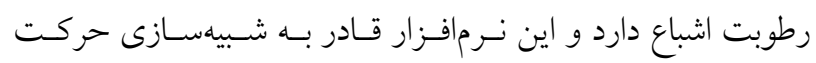

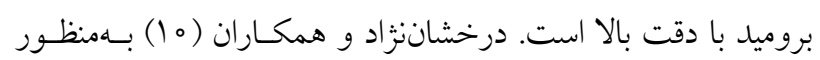

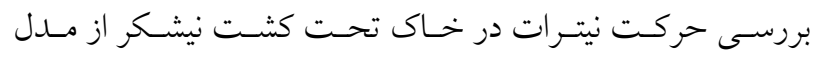

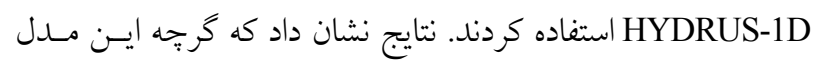
توانست براورد خوبى از روند حركت نيترات در خاك انجام دهــد، ولى مقادير بهينه شده (برازش داده شده) توسط آن از ميـزان تعيسين

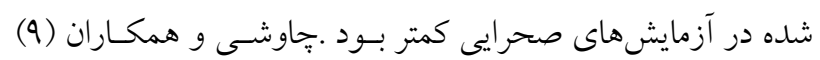

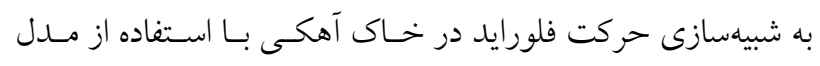

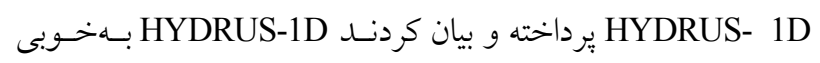

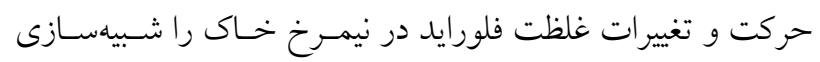

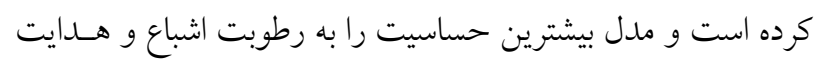
هيدروليكى اشباع براى شبيه سازى را دارد.

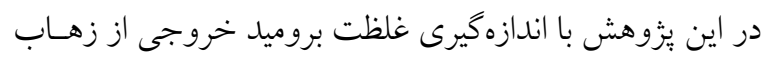

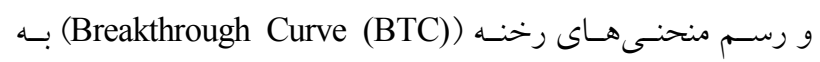

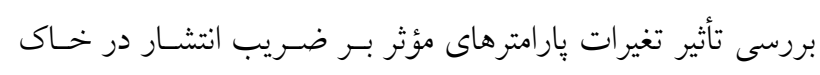
اشباع برداخته شد.

\section{مواد و روشها}

در اين بزوهش از يكى ستون آزمايشخاهى براى شبيهسـازى بسـتر

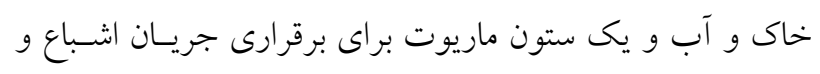

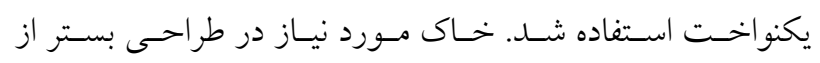

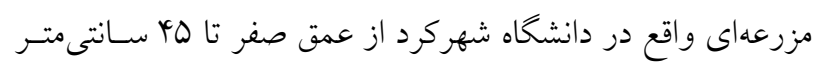

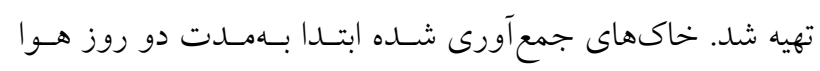

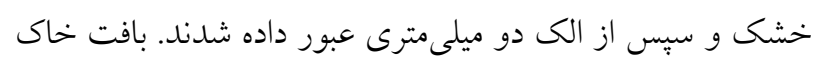

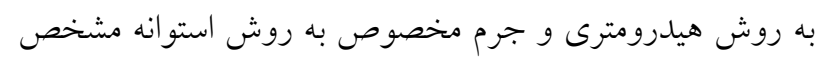

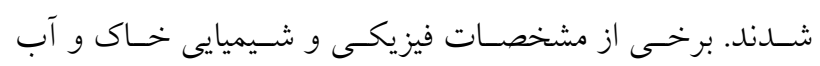
استفاده شده در جدول او Y ارائه شده است.
Ks هدايت هيدروليكى اشباع (LT

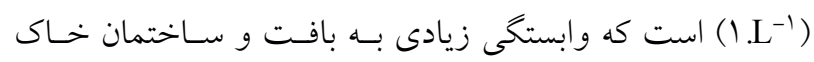

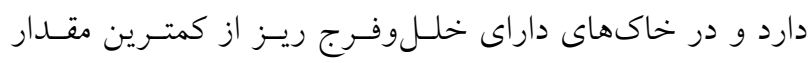
برخوردار است،: Se اشباع نسبى يا درجه اشباع مؤثر، :1 يـارامتر

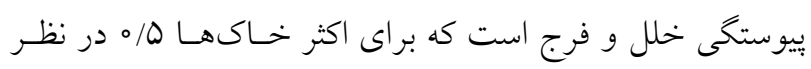

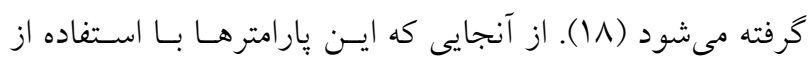

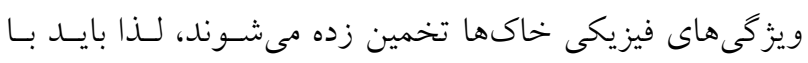
دقت بيشترى براورد شوند.

بروميد و شبيهسازى آن

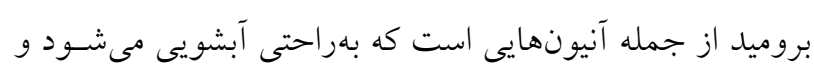

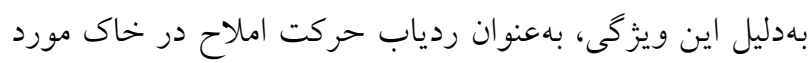

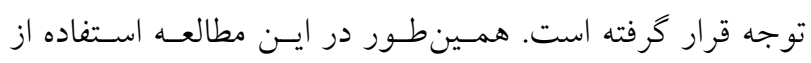

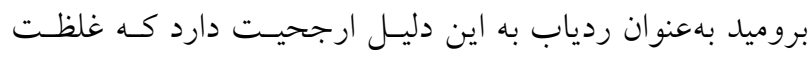

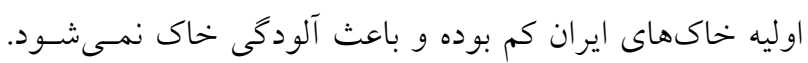

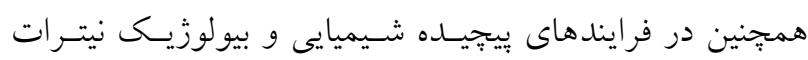

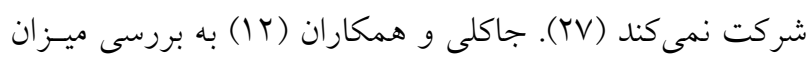

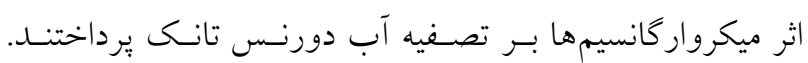

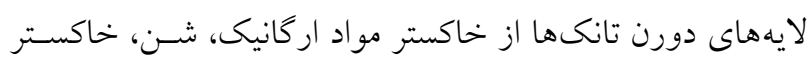

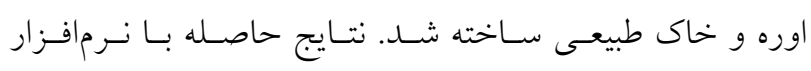
شبdrus-1D

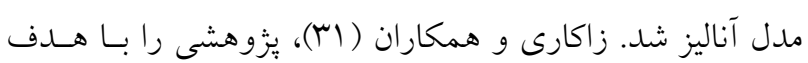

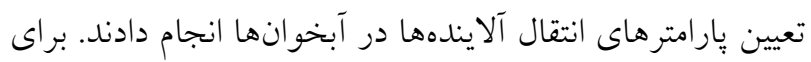

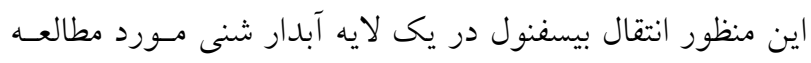
قرار گرفت. سبس مدل غيرتعـادلى بـر دادههـاى منحنسى رخنسه

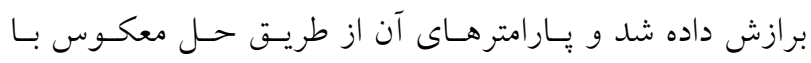

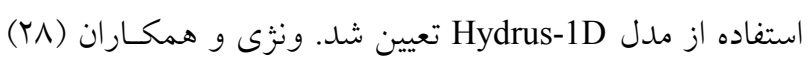
در يزوهش هاى خود نشان دادند كه مدل Hydrus-1D مى توانــ

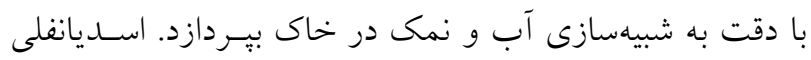

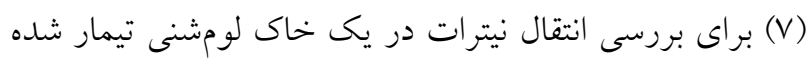

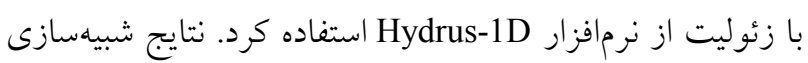

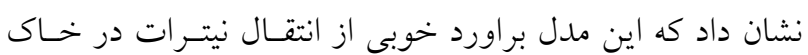


نشريه علوم آب و خاك (علوم و فنون كشاورزى و منابع طبيعى) / سال بيست و سه / شماره سوم / پاييز \هـ|

جدول ا. مشخصات فيزيكى و شيميايى خاك مورد استفاده در ستون

\begin{tabular}{|c|c|c|c|c|c|c|c|c|c|c|c|}
\hline كربن آلى & $\mathrm{Br}$ & $\begin{array}{c}\mathrm{SO}_{{ }^{-}}{ }^{-} \\
(\mathrm{mg} / \mathrm{lit})\end{array}$ & $\mathrm{NO}_{r}^{-}$ & $\begin{array}{c}\text { EC } \\
(\mathrm{dS} / \mathrm{m})\end{array}$ & $\mathrm{pH}$ & $\begin{array}{c}\mathrm{P}_{\mathrm{b}} \\
\left(\mathrm{gr} / \mathrm{cm}^{r}\right)\end{array}$ & $\mathrm{n}$ & سيلت & شن & رس & بافت خاك \\
\hline$\circ / Y \Lambda$ & $\%$ & $\circ / \circ 0$ & $\varphi / 04$ & r & $\mathrm{V} / \mathrm{N}$ & $1 / \pi \wedge$ & 49 & $\uparrow \wedge$ & YY & r^ & لوم رسى \\
\hline
\end{tabular}

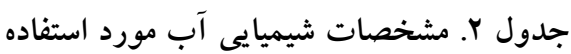

\begin{tabular}{|c|c|c|c|c|c|c|}
\hline $\mathrm{pH}$ & $\begin{array}{c}\mathrm{EC} \\
(\mu \mathrm{mho} / \mathrm{cm})\end{array}$ & $\begin{array}{c}\mathrm{NO}_{r}^{-} \\
(\mathrm{mg} / \mathrm{lit})\end{array}$ & $\begin{array}{c}\mathrm{SO}_{\varphi}^{-} \\
(\mathrm{mg} / \mathrm{lit})\end{array}$ & $\begin{array}{c}\text { Br تزريق شده } \\
\text { (mg/lit) }\end{array}$ & $\begin{array}{c}\mathrm{NO}^{-} \\
(\mathrm{mg} / \mathrm{lit})\end{array}$ & $\begin{array}{c}\mathrm{NH}_{r} \\
(\mathrm{mg} / \mathrm{lit})\end{array}$ \\
\hline$V / 9$ & MTO & TY & $10 / V$ & iq & $\circ / \circ 0$ & o/or \\
\hline
\end{tabular}

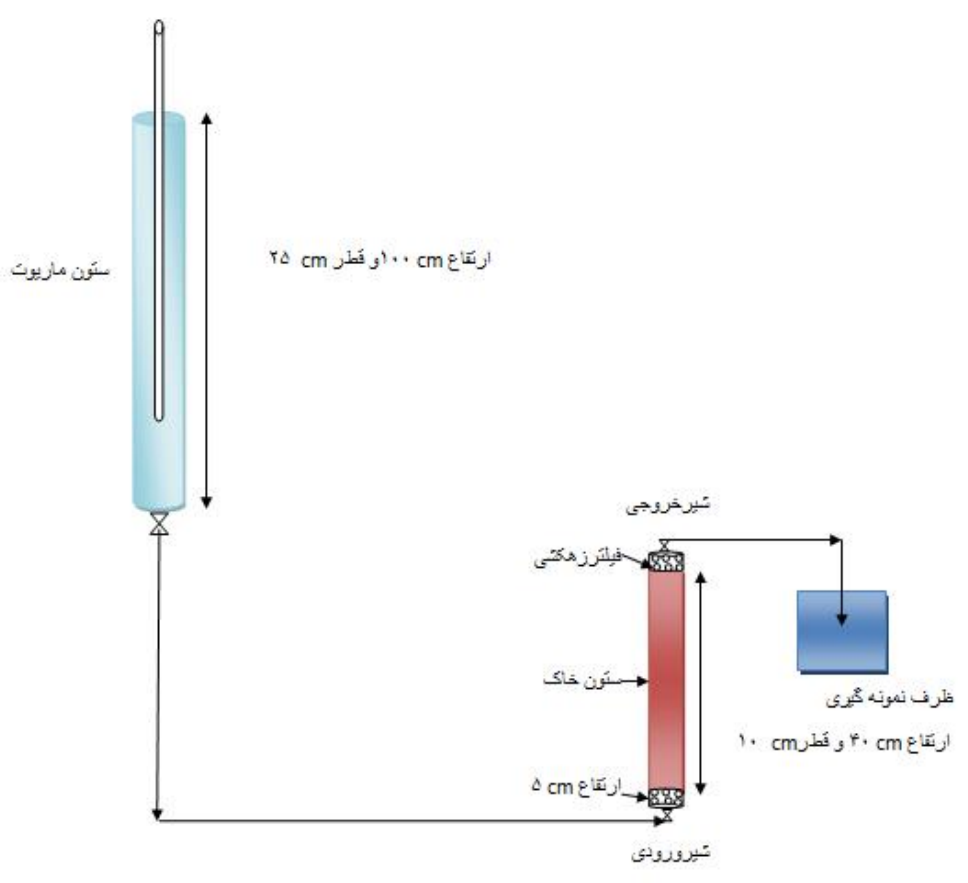

شكل ا. تصوير شماتيك ازمدل فيزيكى آماده شده براى مطالعه ستونى

استفاده شـد. يـك عـدد شـير قطـع و وصـل روى خروجسى و

ورودى ستون نصب شد. (شكل ()

براى بركردن بستر، ابتدا يك سر ستون با در يوش از جـسنس

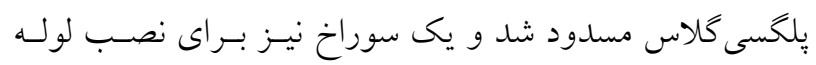

مربوط به جريان ورودى روى آن ايجاد شد. كـل ارتفـاع سـتون

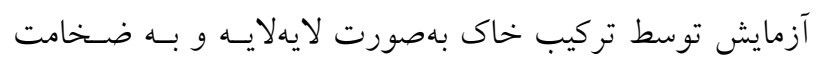

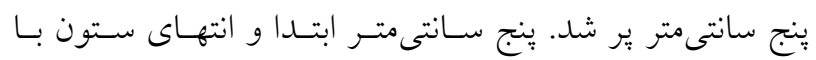

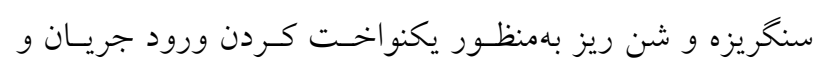

تهيه ستونهاى آزمايشى و آمادهسازى مدل فيزيكى براى تهيه مدل فيزيكى ابتدا ستونهاى آزمايش طراحسى شــند.

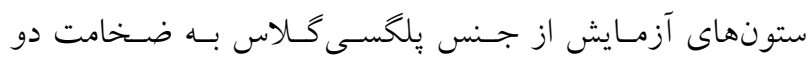
ميلى متر انتخاب شدند. ستونهـاى يلخسـى گـلاس در دو طـول

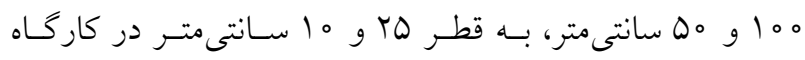
تحقيقاتى يزوهشخاه نفت تهران ساخته شدند بهطورى كه بسـتر به طول • أ سانتى متر در اين ستون شـبيهسـازى شـد، از سـتون

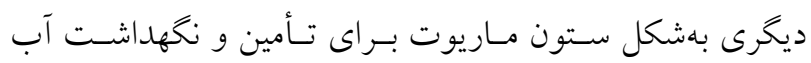


جدول r. دامنه تغييرات ضريب حساسيت (r)

\begin{tabular}{|c|c|c|c|c|}
\hline $\mathrm{S}_{\mathrm{s}}>1 / 0$ & $\circ / \mu<\mathrm{SS}_{\mathrm{S}}<1 / 0$ & $\bullet<\mathrm{S}_{\mathrm{S}}<\circ / \mu$ & $\mathrm{S}_{\mathrm{S}=0}$ & دامنه تغييرات \\
\hline حساسيت زياد & حساسيت متوسط & حساسيت كم & بدون حساسيت & شدت حساسيت \\
\hline
\end{tabular}

بررسى ميـزان اثرگـذارى تغيـــات دادههـاى ورودى بــر خروجىى بهعنوان تحليل حساسيت شناخته شده است. در تحليـل حساسـيت مدل، ابتدا با استفاده از دادهاى ورودي، مــدل اجــرا شــه و نتـايج خروجى بهعنوان دادههاى خروجى بايه در نظر كرفتسه شـد، سـيس

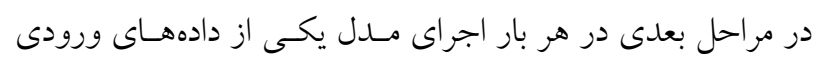

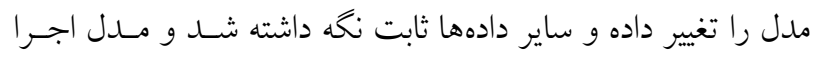
شد. نتايج حاصل با نتايج بايه مقايسه و ضريب حساسـيت محاسـبه شد. بر اين اساس ضريب حساسيت مــل مـورد مطالعسه، از روش ليو و همكاران (4 (1) استفاده شد.

$$
\mathrm{S}_{\mathrm{S}}=-\frac{\frac{\Delta \mathrm{W}}{\mathrm{W}}}{\frac{\Delta \mathrm{P}}{\mathrm{p}}}
$$

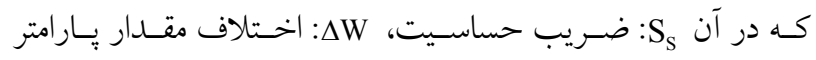

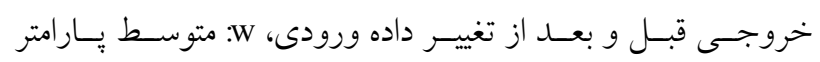
خروجى قبـل و بعـد از تغييـر داده ورودى، دP: اخـــالف مقـدار ورودىى يك يارامتر به مدل و p: متوسط مقدار ورودى يـك يــارامتر

به مدل است. طبقهبندى ضريب حساسيت مطابق جدول ب است.

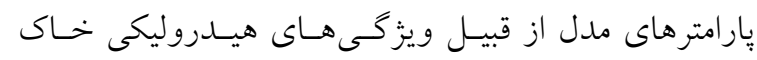

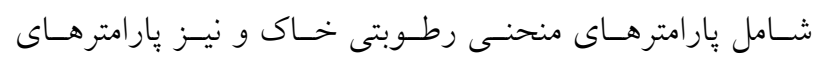

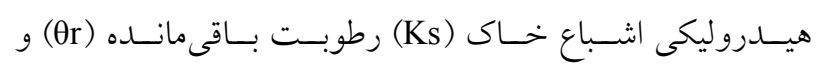

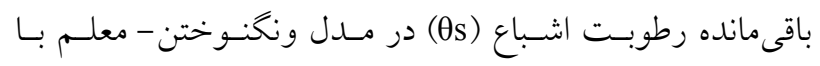
استفاده از اطلاعـات تجزيـه مكـانيكى خـاك (بافـت خــاك) و اندازه كيرى جـرم مخصـوص ظـاهرى بـهوسـيله مــل RETC بيشبينى شدند. در اين بزؤهش مقــار رطوبـت حجمسى و مقـدار تخلخـل اندازهخيرى بهعنوان دادههاى اوليه به مدل داده شـــند، همزمـان با اندازهگيرى مقدار رطوبت، مقدار بروميد موجـود در خـاك و

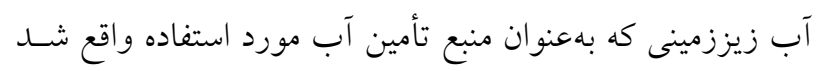

جلو گيرى از شستشوى محتويات داخل آن ير شد (11). بعد از

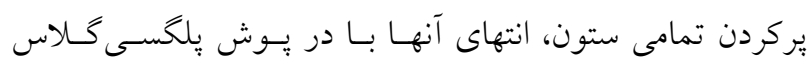
مسدود شد. يكى سوراخ نيـز بــراى نمونسهـيـرى روى دريـوش

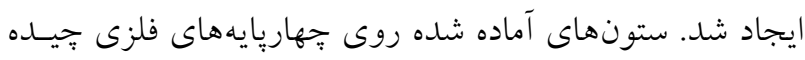
شدند. انجام آزمايش مستلزم وقوع جريان اشباع است. بههمـين منظور براى اطمينان از ير بودن كليه منافـذ موجــود در بسـتر و تخليه كامل هوا از آنها، جريان ورودى به بستر رو به بالا در نظر

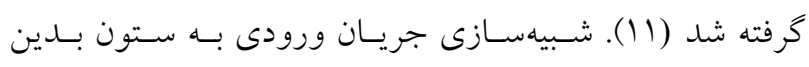
صورت انجام شد كه ابتدا با استفاده از ستون ماريوت به حجـم

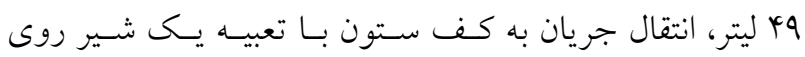
محلول ورودىى به ستون مهيا شد.

\section{نمونهبردارى از جريان بيوسته ورودى به بستر و خروجى از آنها} مقدار غلظت بروميد طبق مطالعات قبلى براى تزريق در آب بين

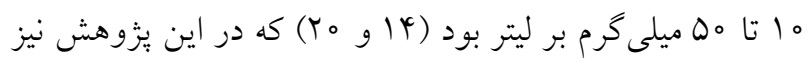

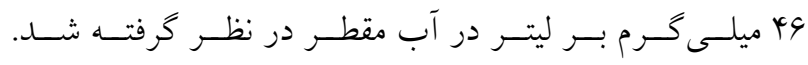
نمونهبـردارى بـر اسـاس حجــم منفــى (Pore volume) (هـر يورواليوم برابر سبها ميلىليتر است) و تقريباً روزانه انجام شـد. نمونهبردارى تـا ه ا حجـم منفـذى ادامسه داشـت. نمونسههـا در

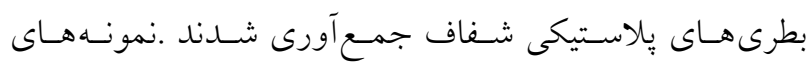

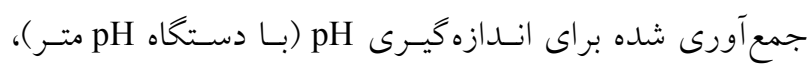
هدايتالكتريكى (دســاه EC متـر)، غلظـت بروميــ (توسط

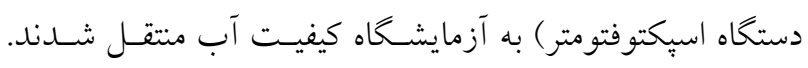
فاكتورهـاى شـيميايى ذكـر شــه در همـان روز نمونـهـــردارى اندازهگيرى شدند، درغير اينصورت در يخجال در دماى كمتـر

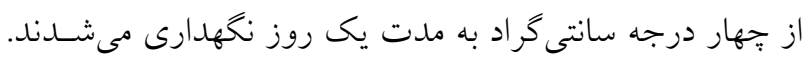
شدت جريان حجمى خروجى از بسترها نيز با تعيين مدت زمان

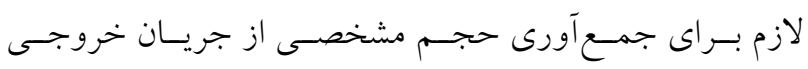
اندازه كيرى شد. 
همانطور كه از نتايج بهدست آمده از تخمسين بـارامتر صسورت

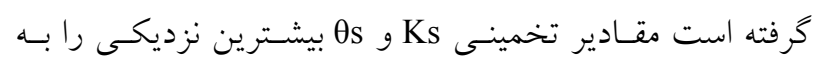
مقادير اندازهگيرى شده و به نوع واقعى خاى دارند، ايسن نتيجـه بيش از اين نيز با توجه به آناليز حساسـيت ؛ــارامترهـا مشـاهده شد، با توجه به بيشترين حساسيت اين دو پيارامتر بيشترين دقت را در تخمين اين بارامترها مشاهده كرد.

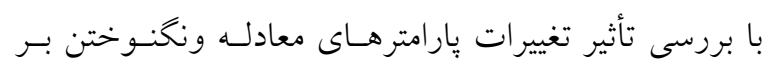

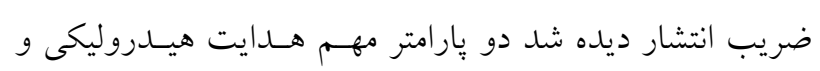
رطوبت اشباع بسيار تأثير كذارند. همانطوركه در شكل (Y) ديله مىشود اين تغييرات در هدايتهيدروليكى شديدتر است.

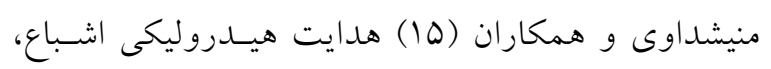
رطوبت اشباع و رطوبت باقىمانده، آزادىفر و همكاران (N)

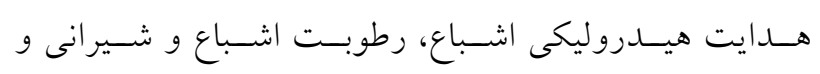

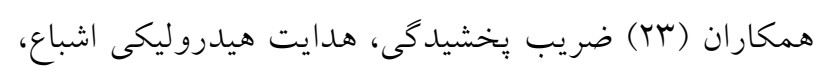
رطوبت اشباع را بهعنوان حساسترين پارامترها بيان كردنـد.

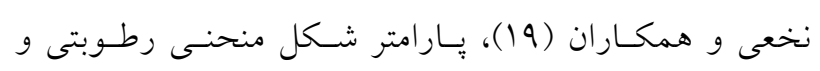

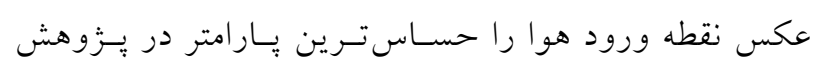
خود بيان كردند. همزمان با استفاده از شاخص ضريب تبيين از نمايههاى،

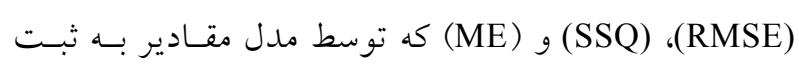
رسيده بود، از يك طرف براى مقايسه ميزان خطاى بهوجــود

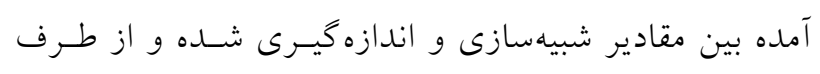
ديخر براى شناخت توانايى شبيهسـازى مـدل مـورد اسـتفاده

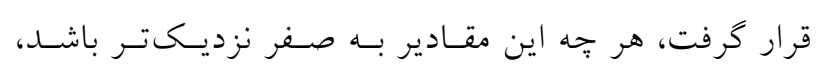
خطاى مدل كمتر است. با توجه به مقادير R شكل (r) و مقادير خطا جــدول (צ)، هـر قدر مقادير R بيشتر و در واقع بالاتر از هو درصــ باشــد و مقـادير

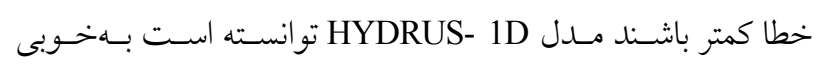
غلظت بروميد را شبيهسازى كند و همانطور كـه در شـكل باديــه

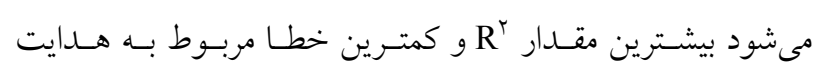
هيدروليكى در دامنه مه درصد كاهش است و اين بيانخر اين اسـت كه تغييرات در اين يارامتر بيشترين تأثير را دارد.

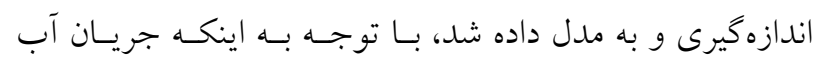
بهصورت اشباع و ماندكار اعمال شد فقط شرايط مرزى در ابتدا و انتها ستون خاى تعريف شد. در مرز بالايى (ورودى) سـتون، جريان ثابت و براى مرز پايينى (خروجى) ستون، جريان ثابت با يتانسيل فشارى صفر در نظر گرفته شد.

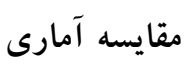
براى ارزيابى كارايى واسنجى و اعتبارسنجى مدل از نمايسههـى آمــارى كـه توسـط مــدل HYDRUS-1D محاسـبه ميشـود،

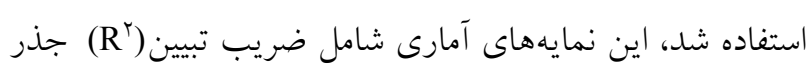

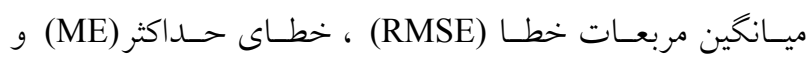
مجموع مربعات خطا (SSQ) هستند كـه توسـط مــل محاسـبه مى شوند.

\section{نتايج و بحث}

با توجه به اينكه سرعت آب در جريان آبهاى زيرزمينسى بـين

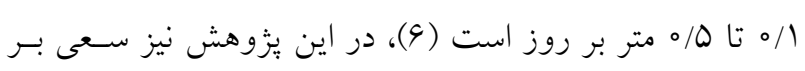

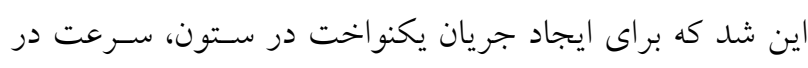

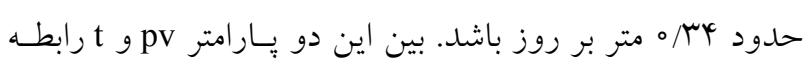

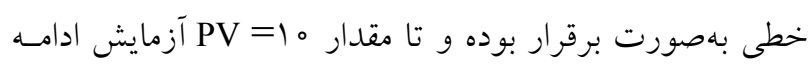
بيد اكرده است.

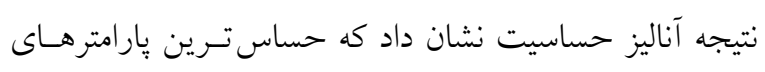
هيدروليكى ks و قs بودند بهطورى كه ضـريب انتشـار و منحنى رخنه به ks حساستر است. ضريب انتشار در بهتـرين حالـت بـا نرمافزار Hydrus-1D برابر \$ \& سانتى متر تخمين زده شد. بـراى بررسى تأثير تغييرات يارامترهاى هيـدروليكى و رطـوبتى بــر ايسن

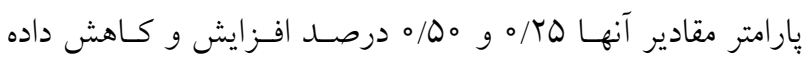
شدند. جدول \& مقادير آمارى و هيدروليكى بهينه بهدست آمــه و جدول ه ميزان حساسيت يارامترهاى هيـدروليكى از شـبيهسـازى مدل را نشان مىدهد. نخعى و همكاران (19) به بررسى تخمسين يارامترها و توابع هيدروليكى خـاك اشـباع بـا مــدل Hydrus-1D يرداختند و به اين نتيجه رسيدند كـه Or حـــاقل حساسـيت رادر

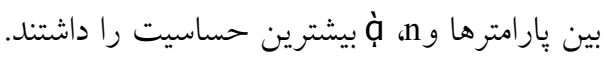


جدول f. نتيجه تخمين پِارامترهاى هيدروليكى و بارامترهاى بهينه در مدل و مقادير آمارى مربوط

\begin{tabular}{|c|c|c|c|c|c|c|c|c|c|c|}
\hline ME & RMSE & $\mathrm{R}^{r}$ & $\Theta \mathrm{s}$ & $\Theta \mathrm{r}$ & $\begin{array}{c}\square \\
(1 / \mathrm{cm}) \\
\end{array}$ & $\mathrm{n}$ & I & $\begin{array}{c}\mathrm{Ks} \\
(\mathrm{cm} / \mathrm{hr})\end{array}$ & $\begin{array}{c}\mathrm{D} \\
(\mathrm{cm})\end{array}$ & \\
\hline & & & $0 / \mathbb{k V}$ & $\circ / \circ \Delta$ & $0 / 01$ & $1 / T \Lambda$ & $\circ / 0$ & $1 / 0 Y$ & 0 & مقادير بهينه شده \\
\hline - & o/AK & $\circ / 19$ & $0 / 4 y$ & $\circ / \vee V \Delta$ & 01019 & $1 / 4 \mid$ & $\circ / 0$ & $1 / 04$ & $4 / 0 q$ & مقادير اوليه \\
\hline
\end{tabular}

جدول ه. ميزان حساسيت بار امترهاى ورودىى

\begin{tabular}{|c|c|c|}
\hline يارامترهاى ورودى مدل & ضريب حساسيت(SS) & شدت حساسيت \\
\hline$\theta_{\mathrm{s}}$ & $0 / 90$ & متوسط \\
\hline$\theta_{\mathrm{r}}$ & $\circ$ & بلدون حساسيت \\
\hline$(\mathrm{cm} / \mathrm{hr}) \mathrm{k}_{\mathrm{s}}$ & r/GY & زياد \\
\hline$\alpha$ & $\circ$ & بدون حساسيت \\
\hline I & $\circ$ & بدون حساسيت \\
\hline $\mathrm{V}\left(\mathrm{cm}^{\gamma} / \mathrm{hr}\right)$ & 。 & بدون حساسيت \\
\hline
\end{tabular}
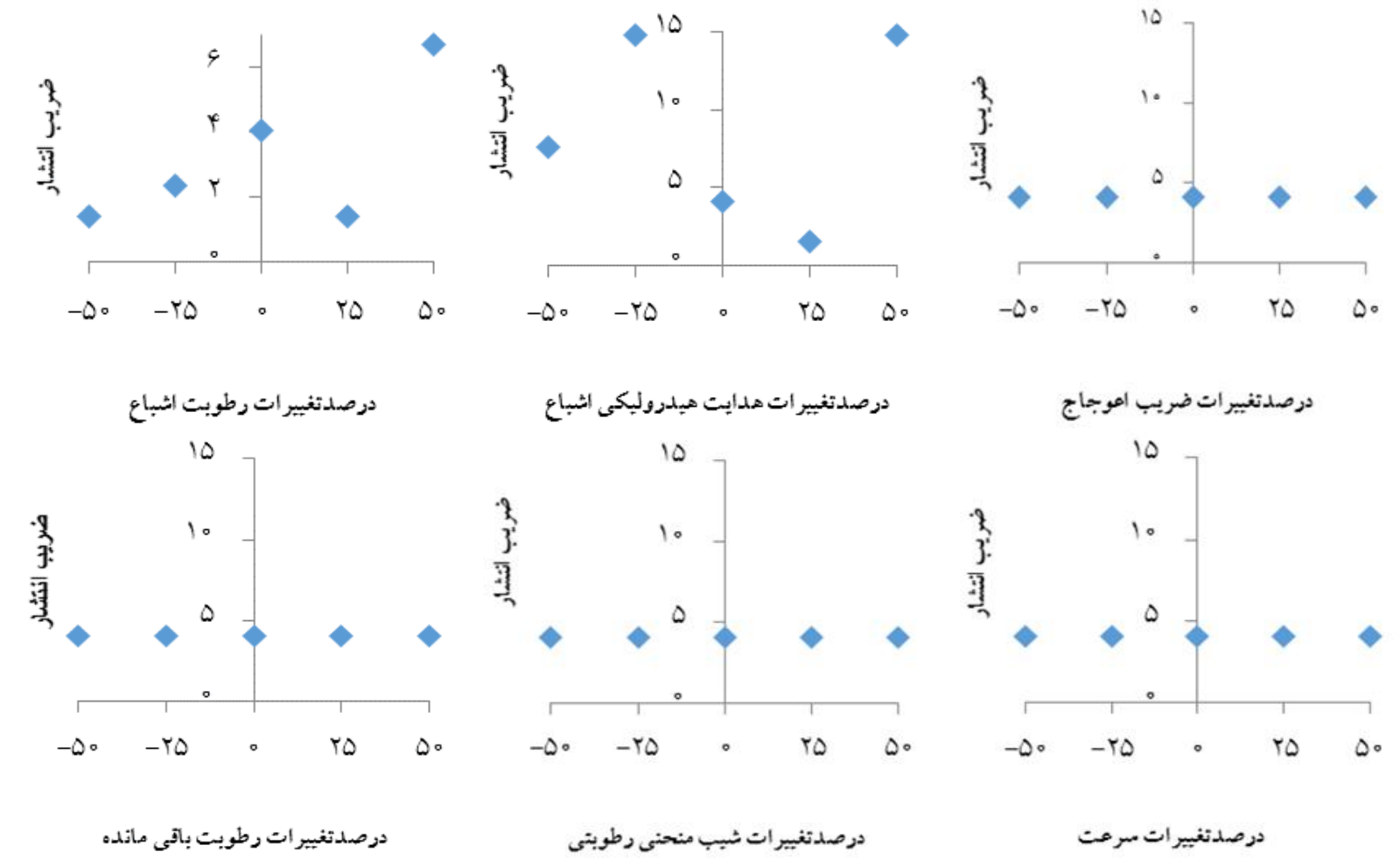

شكل r. آناليز حساسيت ضريب انتشار نسبت به تغييرات رطوبت اشباع، هدايت هيدروليكى اشباع، ضريب اعوجاج، رطوبت باقىمانده، شيب منحنى رطوبتى و سرعت 
نشريه علوم آب و خاك (علوم و فنون كشاورزى و منابع طبيعى) / سال بيست و سه / شماره سوم / باييز \هـ|
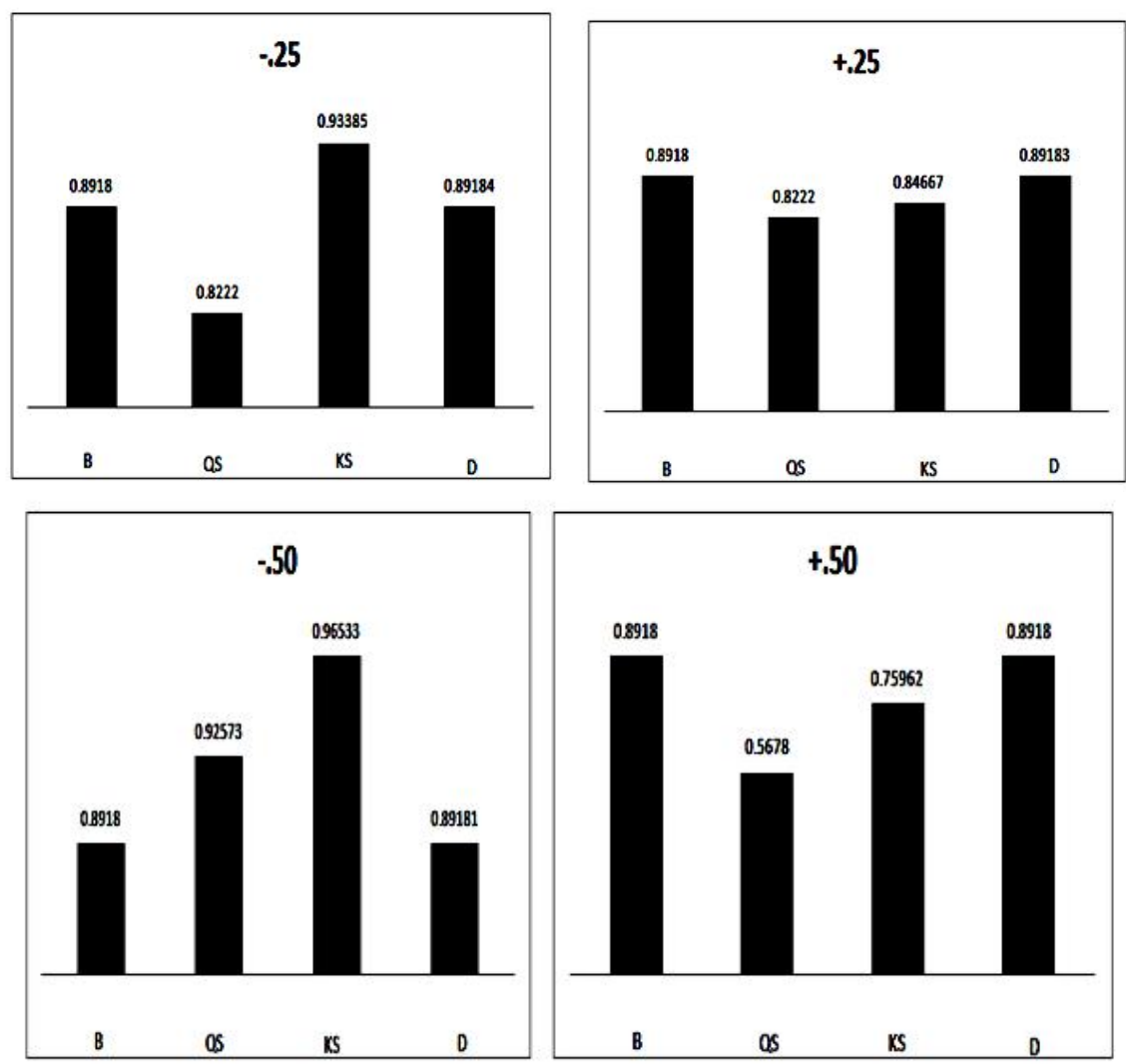

شكل r. مقادير R بار امترهاى هيدروليكى

جدول و. آناليز آمارى و براورد ميزان خطا و درصدتغييرات

\begin{tabular}{|c|c|c|c|c|c|c|}
\hline$(-\circ / 0 \circ)$ & $\left(+\circ / 0_{\circ}\right)$ & $(-\circ / T \Delta)$ & $(+\circ / T Q)$ & (مقدار بهينه) & يار امترهاى امارى & \\
\hline$-0 / 01$ & $-0 / 04$ & $-0 / 01$ & $-0 / 0 \psi^{4}$ & $-0 / 0 r$ & ME & \multirow{3}{*}{$\theta \mathrm{s}$} \\
\hline $0 / 9 T$ & $\circ / V_{0}$ & $O / Y Y$ & $O / Y Y$ & $0 / 14$ & SSQ & \\
\hline $0 / 04$ & $0 / 1 r$ & $0 / 09$ & $\circ / 10$ & $\circ / \wedge$ & RMSE & \\
\hline$-0 / 01$ & $-0 / 09$ & $01 /-0$ & $-0 / 04$ & $-0 / 0 r$ & ME & \multirow{3}{*}{ Ks } \\
\hline $0 / 4 q$ & 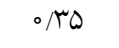 & $\circ / \wedge \circ$ & $0 / r$ &.$/ 14$ & SSQ & \\
\hline $0 / 0 \psi^{4}$ & $0 / 11$ & $0 / 09$ & $0 / 10$ & $\% / \wedge$ & RMSE & \\
\hline
\end{tabular}

HYDRUS-1D

كردند كه با نتايج يزّوهش حاضر مطابقت دارد.

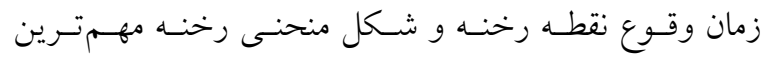

مشخصات منحنى رخنه در تعيـين عملكـرد هسـتند (Q (1). نقطـه رخنه زمانى فرا مىرسد كه غلظت يون در جريان خروجى به سـه تا ينج درصد غلظت آن در جريان ورودى برسد. نقطه اشـباع نيـز زمانى فرا مىرسد كه غلظت يون در جريـان خروجسى بـه مقـدار
بهطور كلى مقايسه تمـامى شـاخص هـاى آمـارى نشـان داد كـه شبيهسازى حركت يون بروميد توسط مدل Hydrus-1D خــوب انجام شده است. اسديان فلى (V)، مرادزاده و همكـاران(IV) بـا بـان شبيهسازى يون نيترات و يانگ و همكاران (ro) با شـبيهسـازى حركـت آب توسـط مـــل HYDRUS- 1D، مقـــار ضــريب همبستكى را /99/ گزارش كردند. همجنين آزادىفر و همكاران به (^) 


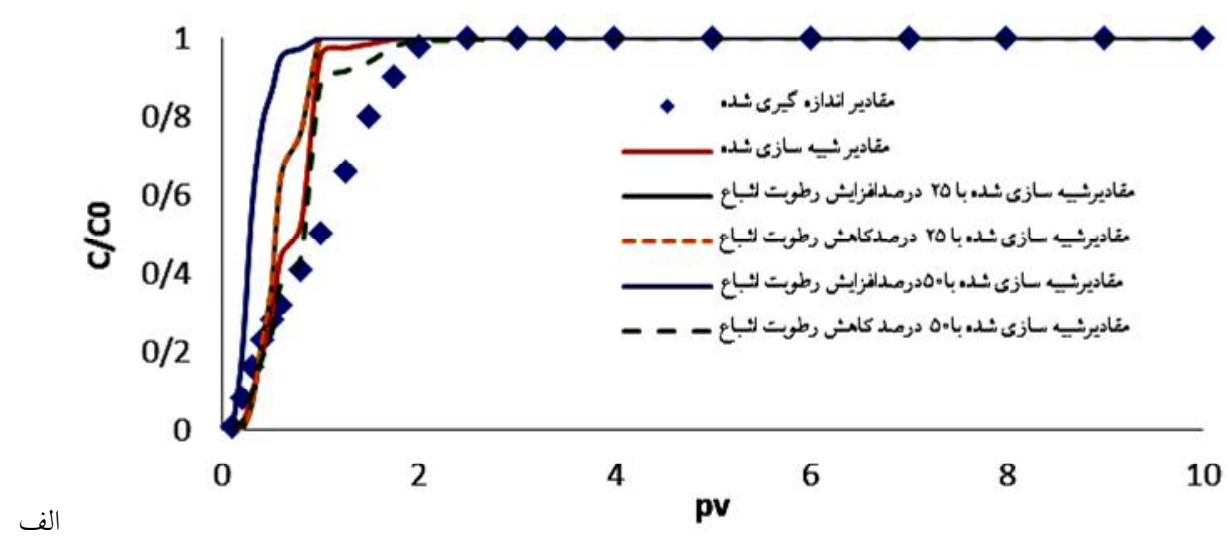

الف

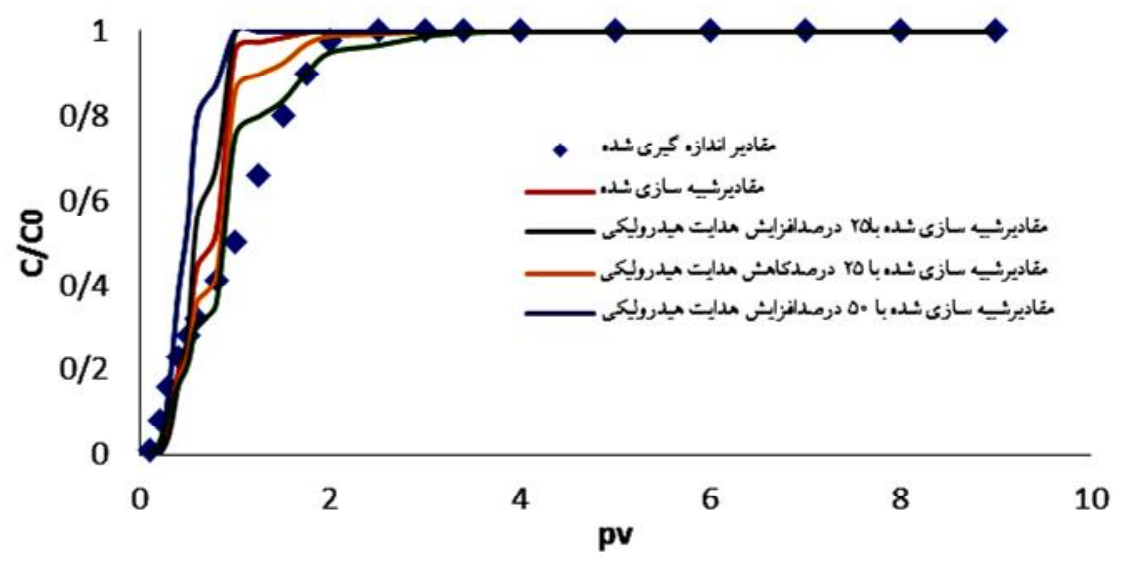

ب

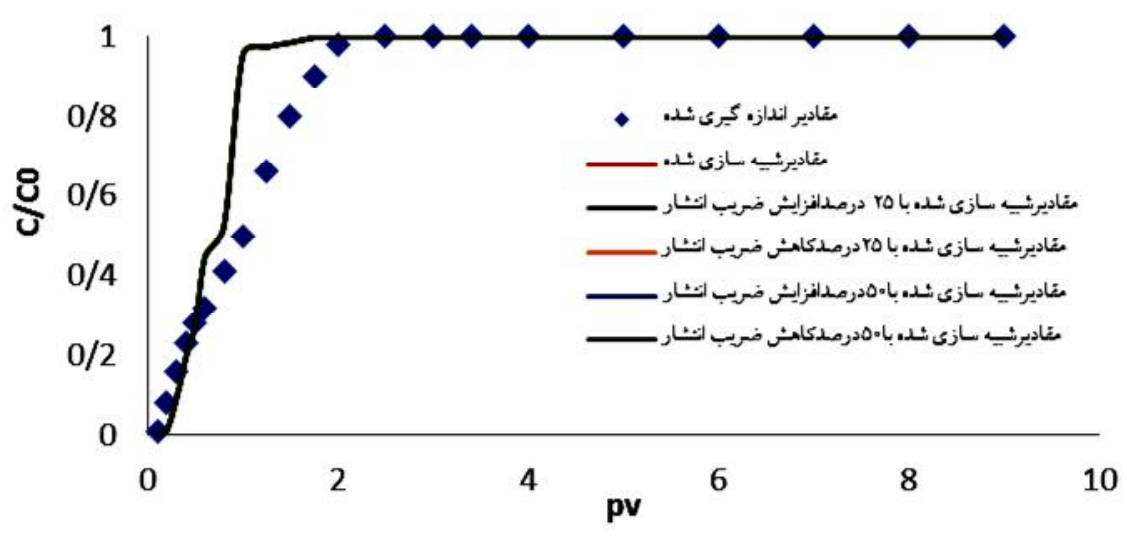

ج

شكل f. آناليز حساسيت براى بارامتر: الف) رطوبت اشباع، ب) هدايت هيدروليكى اشباع و ج) ضريب انتشار

ستون جاذب است كـه در آن تغيــرات غلظـت جـذب شـــه يـون

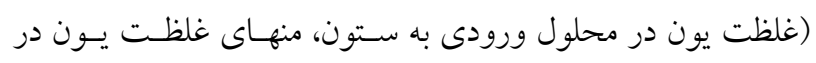

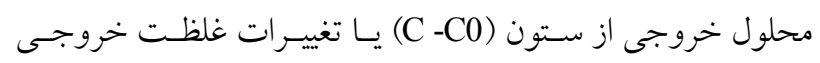

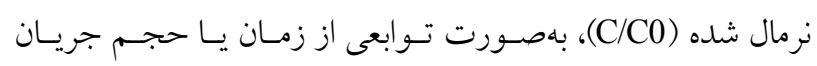

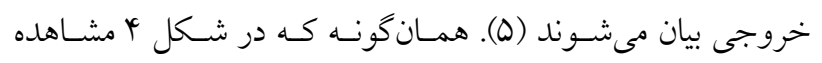

ثابتى برسد، هر تهند كه بستر ستون بهطور كامل اشباع نشده باشد،

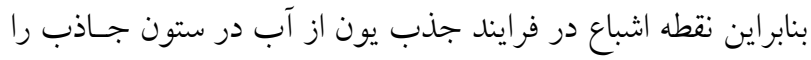

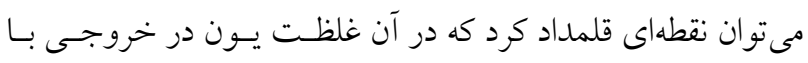

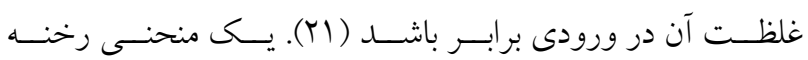

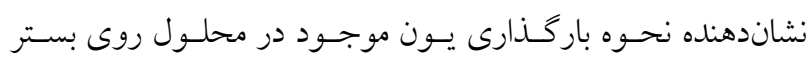


مىشود منحنى هاى رخنه برازش داده شده با مــل HYDRUD-1D بهدست آوردند.

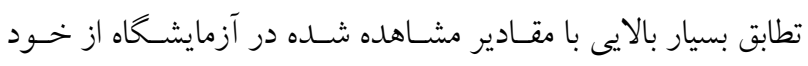

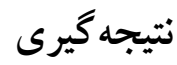

دراين يزوهش به واسنجى و اعتبار سنجى مدل HYDRUS-1D بـا استفاده از دادههاى غلطت برداشت شده بررسى شد. با مـدلسـازى معكوس و با استفاده از يُارمترهاى هيـدروليكى خـاك، يارامترهـاى انتقال املاح براورد شد. نتـايج ايـن يـزَوهش نشـان داد كـهـ مقـدار

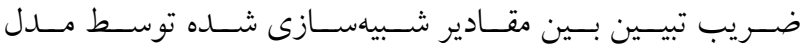
HYDRUS-1D و مقادير مشاهده شده بـين QV/ إهـ

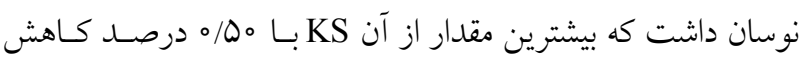

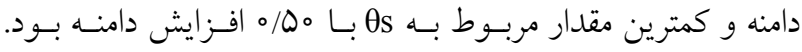
كمترين مقدار ME مربـوط بــ Ks بـا مقــدار ضـريب تبيسين 99/ه درصد است كه بيان كننده بيشترين تـأثير در مقـدار ضـريب انتشـار است. مقدار ضريب حساسيت اين پيارامتر برابر با ب Y است است.

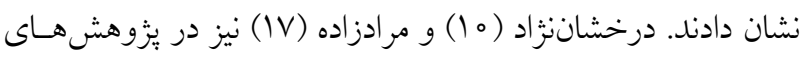
خود اين مسئله را تأييد كردهاند. شـكل بأنتـايج تحليـل حساسـيت مدل HYDRUD-1D را بهترتيب براى سه يارامتر هيدروليكى مهـم رطوبت اشباع، هدايت هيدروليكى اشـباع و ضـريب انتشـار نشـان مىدهد. همانطور كه از شكل مشخص است كمترين تأثير مربـوط

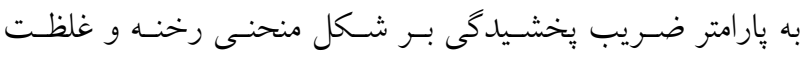

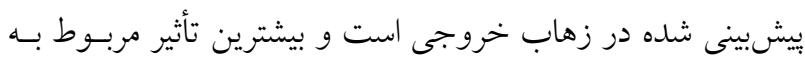
يارامتر هدايت هيدروليكى اشباع است. اين نتايج با يزوهش سلامتى و همكاران (YT) قابل مقايسـه

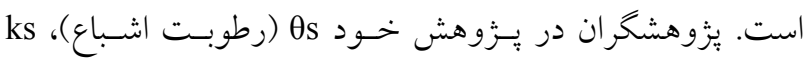

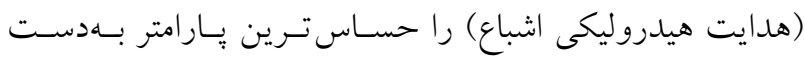

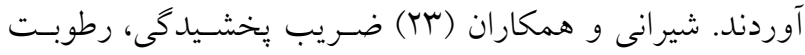
اشباع و رطوبت باقىمانـده را بـهنعـوان حسـاستـرين يـارامتر

منابع مورد استفاده

1. Abbasi, F. 2013. Advance soil physics. 2nd edition. Tehran University press. Tehran. Iran (In Farsi).

2. Abbasi, F., D. Jacques, J. Simunek, J. Feyen and M. Th. Genuchten. 2003. Inverse estimation of the soil hydraulic and solute transport parameters from transient field experiments: heterogeneous soil. Transaction of the ASAE 46 (4): 1097-1111.

3. Abbaspour, K. C. and R. Schulin. 1996. Two dimensional flow and transport in unsaturated soils. PP: 108-119. Federal Office of Environment, Forests and Landscape, Bern, Switzerland.

4. Afyuni, M., M. G. Wagger and R. B. Leidy. 1997. Runoff of two sulfonyl urea herbicides in relation to tillage system and rainfall intensity. Journal of Environmental Quality 26: 1318-1326.

5. Aksu, Z. and F. Gonen. 2004. Biosorption of phenol by immobilized activated sludge in a continuous packed bed: prediction of breakthrough curves. Process Biochem Biochemistry Journal 39: 599-613.

6. Al-Tabbaa, A., J. M. Ayotamuno and R. J. Martin. 2000. One-dimensional solute transport in stratified sands at short travel distances. Journal of Hazardous Material 73: 1-15.

7. Asadian Feli, Z. 2013. Effect of irrigation with municipal wastewater and potassium zeolite. Journal of Hydrology 42: 99-111.

8. Azadifar, A., A. Soltani mohammadi, H. Moazed and A. Farrokhian Firuz. 2017. The study of nitrate dispersivity in sandy soil using HYDRUS-1D model. Iranian Journal of Soil and Water Research 47(4): 765-774. (In Farsi).

9. Chavoshi, E., M. Afyuni and M. A. Hajabbasi. 2015. Simulation of fluoride transport in a calcareous soil using HYDRUS-1D. Journal of Water and Soil Science 19(72): 205-215. (In Farsi).

10. Derakhshannejad, Z., GH. Sayyad and A. R. Jjafarnejadi .2010. Simulation of nitrate transportation in a soils under sugarcane cultivation using HYDRUS-1D solute transport model. In: Proceeding of the First National Conference on Sustainable agriculture and healthy product production, Research Center for Agriculture and Natural Resources of Isfahan. (In Farsi).

11. Healy, M. G., T. G. Ibrahim, G. J. Lanigan, A. J. Serrenho and O. Fenton. 2012. Nitrate removal rate, efficiency and pollution swapping potential of different organic carbon media in laboratory denitrification bioreactors. Ecological Engineering Journal 40: 198-209.

12. JiakeLi, R., Y. Zhao and L. Chen. 2018. Modeling the effects of parameter optimization on three bio retention tanks using the HYDRUS-1D model. Journal of Environmental Management 217: 38-46. 
13. Li, Z. M., E. O. Skogley and A. H. Ferguson. 1993. Resin adsorption for describing bromide transport in soil under continuous or intermittent unsaturated water flow. Journal of Environmental Quality 22: 715-722.

14. Liu, H. F., M. Genard, S. Guichard and N. Bertin. 2007. Model-assisted analysis of tomato fruit growth in relation to carbon and water fluxes. Journal of Experimental Botany 58(13): 3567-3580.

15. Maneshdavi, M., A. R. Jafarnejadi, G. A. Sayyad and H. Shirani. 2015. Inverse modeling of e.coli mobility through the soil by HYDRUS-1D code using equilibrium and non-equilibrium equations. 38(3):105-115.

16. Maroufpour, E., H. Kashcoli, H. Moazed and H. M. Vali Ssamani. 2008. Comparative study of mathematical models of Fried-Combernous Brigham to dispersion of conservative pollutants in the homogeneous sandy soil. Journal of Agricultural Science 30: 77-89. (In Farsi).

17. Moradzadeh, M., H. Moazed and GH. Sayyad. 2012. Simulation of Nitrate Ion Leaching in a Sandy Loam Soil Treated with Zeolite using Hydrus-1D Model. Journal of Soil and Water 23 (1):95-107. (In Farsi)

18. Mualem, Y. 1976. A new model for prediction of the hydraulic conductivity of unsaturated porous media. Water Resource Research Journal 12(3): 513-522.

19. Nakhaei, M., V. Amiri and M. Vadiati. 2015. Inversely estimation of hydraulic parameters and functions of unsaturated soil using disk infiltrometer experiment data. Journal of Soil and Water Conservation 4(4): 40-48. (In Farsi).

20. Paramasivam, S., A. K. Alva, A. Fares and K. S. Sajwan. 2002. Fate of nitrate and bromide in an unsaturated zone of a sandy soil under citrus production. Journal of Environmental Quality 31: 671-681.

21. Paul Chen, J., J. T. Yoon and S. Yiacoumi. 2003. Effects of chemical and physical properties of influent on copper sorption onto activated carbon fixed-bed columns. Carbon 41: 1635-1644.

22. Salamati, N., M. Delbari, F. Abbasi and A. Sheini Dashtgol. 2016. Simulation of Water and Nitrate Transport in Soil Using HYDRUS-1D Model in Furrow Irrigation of Sugarcane. Journal of Water and Soil Science 19(74):179-192. (In Farsi).

23. Shirani, H., M. Kord, G. A. Sayyad and H. Naghavi. 2011. Simulating bromide transport in disturbed soil columns using HYDRUS-1D model. Journal of Watershed Management Research 92: 20-31. (In Farsi).

24. Simunek, J., M. Sejna and M. Th. Van Genuchten. 1998. The HYDRUS-1D software package for simulating the one-dimensional movement of water, heat, and multiple solute in variably saturated media, Version 2.0, IGWMCTPS-70, Int. Ground Water Modeling Center, Colorado School of Mines, Golden, Co.

25. Simunek, J., M. Th. Van Genuchten and M. Sejna. 2008. Development and applications of the HYDRUS and STANMOD software packages and related codes. Vadose Zone Journal 7: 587-600.

26. Singh, R. M. and B. Datta. 2004. Groundwater pollution source identification and simultaneous parameter estimation using pattern matching by artificial neural network. Environ Forensics 5(3): 143-153.

27. Starr, J. L., J. Y. Parlange and C. R. Frink. 1986. Water and chloride movement through a layered field soil. Soil Science Society of American Journal (SSSAJ) 50: 1384-1390.

28. WenZhi, Z., Ch. XU, J. WU and J. Huang. 2014. Soil salt leaching under different irrigation regimes: HYDRUS-1D modelling and analysis. Journal of Arid Land 6(1): 44-58.

29. Xie, T., X. Liu and T. Sun. 2011. The effects of groundwater table and flood irrigation strategies on soil water and salt dynamics and reed water use in the yellow river delta, China. Ecological Modelling Journal 222: 241-252.

30. Yiang, M., F. Shaoyuan, S. Dongyuan, G. Guangyuo and H. Zailin. 2010. Modeling water infiltration in a large layered soil column with a modified Green-Ampt model and HYDRUS-1D. Computer and Electronic in Agriculture Journal 71: 40-47.

31. Zakari, S., H. Liu, L. Tong, Y. Wang and J. Liu. 2016. Transport of bisphenol-A in sandy aquifer sediment: Column experiment. Chemosphere 144: 1807-1814. 


\title{
Hydraulic Parameters Sensitivity Analysis of Porous Media at Inverse Solution of Bromide Transport
}

\author{
F. Ansari ${ }^{1}$, S. H. Tabatabaei ${ }^{*}$, F. Abbasi ${ }^{2}$ and E. Alaei ${ }^{3}$
}

(Received: June 4-2018 ; Accepted: January 15-2019)

\begin{abstract}
Simulation of water and salt transfer in soil is very effective in managing optimal water and fertilizer use in the field. In this study, the HYDRUS-1D model was used to simulate the transfer of water and bromide in a laboratory column of soil with clay loam texture. Soil hydraulic parameters (including air entry point) $\alpha$, (saturated hydraulic conductivity) $\mathrm{ks}$, (residual moisture content) $\theta \mathrm{r}$ (saturation moisture content) $\theta \mathrm{s}$, (pore and particle joint parameter) 1 (parameter of moisture curve shape) $\mathrm{n}$ through measurement and using Retc software was obtained Solubility transfer parameters including difiusion coefficient and actual velocity were estimated using soil hydraulic parameters and bromide concentration data by reverse modeling method. According to the target coefficients, the sensitivity analysis of the physical model was performed.The results showed that the correlation coefficient of observation and simulation bromide concentration in optimal mode was $0.84 \%$. accordingly, the diffusion coefficient was estimated to be $4.9 \mathrm{~cm}$. based on the results of the sensitivity analysis, the saturation hydraulic conductivity had the greatest effect on the variation of this parameter, so that the amount sensitivity coefficient of this parameter was 2.64 The RMSE coefficient with a value of 0.04 was the lowest and ME coefficient with the value of -0.0001 had the most parameter variations.
\end{abstract}

Keywords: Dispersion, Simulation, Bromide, HYDRUS

1- Department of Water Engineering, Faculty of Agriculture, Shahrekord University, Shahrekord, Iran.

2- Agricultural Engineering Research Institute, Agricultural Research, Education and Extension Organization, Karaj, Iran.

3- Environmental and Biotechnology Department, Research Institute of Petroleum Industry, Tehran, Iran.

*: Corresponding Author, Email: faride.ansari@yahoo.com 